\title{
Effect of single-species and mixed-species leaf leachate on bacterial communities in biofilms
}

\author{
Lan Wu $\cdot$ Christopher B. Blackwood • \\ Laura G. Leff
}

Received: 18 May 2009/Revised: 6 August 2009/Accepted: 24 August 2009/Published online: 4 September 2009

(C) Springer Science+Business Media B.V. 2009

\begin{abstract}
Dissolved organic matter in the form of leaf leachate represents an important carbon and energy source in many lotic ecosystems. In this study, we investigated utilization of mono-specific and mixed-species leaf leachate and impacts on biofilm bacterial community structure. Ceramic tiles were incubated in a Northeast Ohio stream to allow for biofilm development and then exposed in the laboratory to glucose or leachate from: sugar maple (Acer saccharum), pin oak (Quercus palustris), maple + oak, American beech (Fagus grandifolia), witch hazel (Hamamelis virginiana), or beech + witch hazel. Bacterial responses to these amendments were compared to un-amended controls based on fluorescent
\end{abstract}

Electronic supplementary material The online version of this article (doi:10.1007/s10750-009-9935-1) contains supplementary material, which is available to authorized users.

Handling editor: L. Naselli-Flores

L. Wu $(\bowtie)$

School of Life Science, Nanchang University,

Nanchang 330031, China

e-mail:w1690902@hotmail.com

L. Wu · C. B. Blackwood - L. G. Leff

Department of Biological Sciences, Kent State University,

Kent, OH 44242, USA in situ hybridization (FISH) targeting selected taxa and terminal restriction fragment length polymorphism (T-RFLP) of bacterial 16S rRNA genes; also changes in DOC concentrations were quantified. Generally, there were limited differences among communities as a result of leachate amendment, although specific taxa monitored by FISH exhibited differential responses. There was no evidence that mixing of leachate from different leaf species created an effect different than what could be expected based on monospecific experiments. Witch hazel solicited the greatest response, based on T-RFLP data, regardless of whether the community was exposed to witch hazel alone or witch hazel + beech, accounting for $19 \%$ of the variability in Jaccard distance $(P<0.05)$ and $27 \%$ of the variability in Hellinger distance among profiles. In conclusion, we found that leaf leachate can be readily degraded but only in some cases did differences in leaf leachate among tree species cause an alteration in community structure. Mixing of leachate from different leaf species did have an impact on DOC loss but did not alter community structure. The occurrence of particular compounds, such as those in witch hazel, may alter community structure suggesting that the presence and abundance of specific plant taxa can impact bacterial communities.

Keywords Bacteria - Biofilm · In situ hybridization - Leaf leachate $\cdot$ Terminal restriction fragment length polymorphism 


\section{Introduction}

Bacteria are an important component of stream biofilms and play a dominant role in nutrient cycling and energy/carbon flow in lotic systems (Mulholland et al., 1984; Meyer, 1994; Battin et al., 2003). In turn, allochthonous organic matter is a central contributor to carbon and energy in many streams, and impacts the metabolism and abundance of bacteria (Fisher \& Likens, 1973; Webster et al., 1995). In particular, dissolved organic matter (DOM) is the dominant form of organic carbon in aquatic systems (Wetzel, 1992; Münster, 1993) and can be directly used by bacteria (Hall, 1995).

One major form of DOM entering many streams is leaf leachate (Giller \& Malmqvist, 1998). For example, up to $25 \%$ of initial leaf mass is lost within 1 day through leaching (Webster \& Benfield, 1986). Although there have been several studies focused on the effects of leaf leachate on microbial communities in streams (e.g., Koetsier et al., 1997; Strauss \& Lamberti, 2002; Schlief \& Mutz, 2007), little is known about the impact of leachate from different leaf species on specific bacterial taxa or how mixtures of leachate from different leaf species are utilized. The latter point is particularly relevant because, in a given watershed, a variety of tree species are intermingled, creating mixtures of leaf leachate from different sources (Koetsier et al., 1997).

Variations in leachate chemistry among leaf species likely contribute to differences in overall utilization of leachate (Wallace et al., 2008) as well as specific bacterial community structural responses. DOM from leaves includes, among other compounds, sugars (that are utilized rapidly) and polyphenols (Sasaki et al., 2007). Labile compounds can stimulate some bacteria while phenolics can have inhibitory or toxic effects (Fierer et al., 2001; Schlief \& Mutz, 2007). Leachate from different leaf species differs in chemical composition which subsequently effects lability (Cleveland et al., 2004; Wallace et al., 2008).

In addition to differences among leachates from leaves of different species in bioavailability, responses to leachate vary among bacterial taxa. For example, in a study using maple leachate amendments, Acinetobacter calcoaceticus was not affected, the population size of Burkholderia cepacia increased, and Pseudomonas putida was inhibited by the highest leachate concentrations (McNamara \& Leff, 2004a).
In order to examine biofilm bacterial community structure in this study, we used fluorescent in situ hybridization (FISH; Delong et al., 1989) and terminal restriction fragment length polymorphism (T-RFLP; Liu et al., 1997) to detect responses to leaf leachate. FISH has been widely used to describe temporal and spatial changes in structure of aquatic bacterial communities (e. g., Koetsier et al., 1997; Pernthaler et al., 1998; Manz et al., 1999) as well as to examine responses to different environmental conditions (Amann et al., 1990, 1995; Olapade \& Leff, 2004), in spite of methodological limitations (Bouvier \& Giorgio, 2003). Specifically, in this study, we targeted the Beta- and Gamma-Proteobacteria along with A. calcoaceticus and B. cepacia because of their abundance and importance in streams (Leff, 2000; Liu \& Leff, 2002; Araya et al., 2003; Olapade \& Leff, 2006; Santmire \& Leff, 2007). For example, responses to DOM differ between the two species (McNamara \& Leff, 2004a, b), perhaps because A. calcoaceticus can use few simple sugars (Juni, 1978), whereas $B$. cepacia can utilize a broad array of compounds (Lessie \& Gaffney, 1986). Therefore, we hypothesized that responses to different types of leaf leachate would vary among these groups. T-RFLP is a genetic fingerprinting tool that has been widely used in various environments to examine microbial community structure (e.g., Kent et al., 2003; Blackwood et al., 2006; Danovaro et al., 2006; Blackwood \& Buyer, 2007). Marsh (1999) suggests that T-RFLP is a sensitive method which has the ability to detect lessabundant taxa within assemblages, although it does have drawbacks inherent to many PCR-based community fingerprinting techniques.

In this study, we assessed the utilization of leaf leachate from different tree species (singly and in combination) by aquatic bacterial biofilm communities and evaluated the impacts on community structure. Biofilms were selected as the focus because of their widespread occurrence and importance in biogeochemistry of aquatic systems, particularly streams. Responses to monospecific or mixed-species leaf leachate were examined, along with responses to glucose. We hypothesized that bacterial taxa would vary in their responses to leachate of different types because of chemical differences among leaf species which would also be reflected in differences in utilization of leachate among leaves of different species. We also predicted higher bacterial abundance 
on leachate from mixed-species leaves compared with monospecific leachate due to an increased array of potential biochemical niches in the presence of a more diverse suite of chemical resources.

\section{Materials and methods}

\section{Experimental design}

Unglazed, autoclaved ceramic tiles $(5.12 \mathrm{~cm} \times 5.12$ $\mathrm{cm})$ were incubated to allow for biofilm development in the West Branch of Mahoning River, a stream located in Northeastern Ohio (USA), as in Olapade \& Leff (2006). Sets of tiles were positioned in a riffle on 29 November 2007 and 23 February 2008 and retrieved after about 5 weeks for use in two experiments described below. Stream temperature, $\mathrm{pH}$, conductivity (Symphony SP90M5), water velocity (Marsh-McBirney model 201/201D), and turbidity (Hach model 2100P) were measured at the site of deployment in triplicate on each deployment date. Also, triplicate water samples were collected and concentrations of dissolved organic carbon (DOC) (Shimadzu Scientific Instruments TOC5000), nitrate/ nitrite, and soluble reactive phosphate (SRP) (LachAT Quikchem $800 \mathrm{FLA}^{+}$) were measured.

After incubation in the stream, tiles were retrieved and brought to the laboratory where they were placed in 21 beakers with $600 \mathrm{ml}$ of sterile artificial stream water (ASW) containing the following (per liter): $12 \mathrm{mg} \mathrm{NaHCO}_{3}, 7.5 \mathrm{mg} \mathrm{CaSO}_{4} \cdot 2 \mathrm{H}_{2} \mathrm{O}, 7.5 \mathrm{mg} \mathrm{Mg}$ $\mathrm{SO}_{4}, 0.5 \mathrm{mg} \mathrm{KCL}, 10 \mathrm{mg} \mathrm{CaCO}_{3}$ (pH 6.4) (APHA, 1998). Beakers were subjected to various DOM amendments. Leaf leachate was extracted from senescent sugar maple (Acer saccharum), pin oak (Quercus palustris), American beech (Fagus grandifolia), and witch hazel (Hamamelis virginiana), collected from trees at the study site, as described in McNamara \& Leff (2004b). In the first experiment, treatments included: controls with no added leachate, maple leachate, oak leachate, and maple + oak leachate. In the second experiment, treatments included: controls with no added leachate, beech leachate, witch hazel leachate, beech + witch hazel leachate, and glucose. All treatments, including controls, were performed in triplicate, and there were seven tiles per beaker. The concentrations of DOC from leaf leachate and glucose used were $15 \mathrm{mg} / \mathrm{l}$. For mixed-species leachate, the concentrations of DOC from the two species were the same and totaled $15 \mathrm{mg} / \mathrm{l}$.

A portion of leachate from each leaf species was used for chemical analysis. DOC and DON concentrations were measured using a TOC5000 (Shimadzu Scientific Instruments). Total sugar concentrations were determined based on phenol-sulfuric assay (Dubois et al., 1956), and were expressed as glucose equivalents. Concentrations of total phenol compounds were determined by the Folin-Ciocalteu method (Singleton \& Rossi, 1965); tannic acid was used as the standard.

Beakers of tiles were incubated for 11 days (at room temperature in the dark) with stirring at $20 \mathrm{rpm}$ using Phipps and Bird paddle stirrers (Phipps and Bird, Richmond, Virginia) as in Olapade \& Leff (2006). After incubation, three randomly selected tiles were scraped with a sterile toothbrush and scrapings were preserved in $1 \times$ phosphate-buffered saline and 8\% paraformaldehyde, then sonicated (Branson model 2210 ultrasonic bath, Trenton, NJ) for $5 \mathrm{~min}$ in $0.1 \%$ tetrasodium pyrophosphate; samples were stored at $4^{\circ} \mathrm{C}$. The remaining tiles were frozen at $-80^{\circ} \mathrm{C}$ for subsequent DNA extraction. $\mathrm{pH}$ and DOC concentrations of water in the beakers were measured following the same methods (above) for water samples collected from the stream.

\section{Bacterial enumeration}

Total bacterial number was determined by staining cells, concentrated on $0.2 \mu \mathrm{m}$-pore-size black polycarbonate filters (Poretics, Livemore, CA), with 15 $\mu \mathrm{g} / \mathrm{ml}$ DAPI for 3 min (Porter \& Feig, 1980); bacteria in 10 fields per slide were enumerated. The abundance of cells belonging to Beta-Proteobacteria, GammaProteobacteria, A. calcoaceticus, and B. cepacia was enumerated using FISH as described previously (e.g., Olapade \& Leff, 2005; Rubin \& Leff, 2007). Details of methods, probes, and hybridization conditions can be found in Olapade \& Leff (2005). Briefly, samples were concentrated on $0.2 \mu \mathrm{m}$ white polycarbonate filters (Poretics) or Anodiscs (Whatman) depending on the probe and washed with $0.1 \%$ Nonidet P-40 (Sigma). Filters were placed in Petri plates and treated with $40 \mu \mathrm{l}$ Texas Red-labeled probe (Sigma Genosys, Cambridge, UK) at $5 \mathrm{ng} / \mu \mathrm{l}$ final concentration and incubated in the dark at the appropriate temperature for $4 \mathrm{~h}$; probe was diluted in hybridization buffer 
[6 × standard saline citrate (SSC), 0.02 M Trizma base (pH7.0), $0.1 \%$ sodium dodecyl sulfate (SDS), and $0.01 \%$ polyadenylic acid]. Then, cells were washed twice with $400 \mu \mathrm{l}$ washing buffer $(0.9 \mathrm{M} \mathrm{NaCl}$ or $0.009 \mathrm{M} \mathrm{NaCl}$ depending on the probe) with a $10 \mathrm{~min}$ incubation time in between. After a second $10 \mathrm{~min}$ incubation, filters were rinsed twice with $400 \mu \mathrm{l}$ water, and hybridized cells of 50 fields per filter were enumerated.

DNA extraction and terminal restriction fragment length polymorphism (T-RFLP)

For DNA extraction, biofilms were scraped from tiles using a razor blade; approximately $150 \mathrm{mg}$ wet weight was recovered per beaker. DNA was isolated from the biofilms using the PowerSoil DNA extraction kit (MoBio Laboratories, Carlsbad, CA) following the manufacturer's instructions. Bacterial 16S rRNA genes were amplified with Eub338F-0-IFam mixed with Eub338F-II-III-Fam ( $5^{\prime}$-ACT CCT ACG GGA GGC WGC-3' and 5'-ACA CCT ACG GGT GGC WGC-3', Fam labeled) and 1392R (5'ACG GGC GGT GTG TAC A-3') (Blackwood et al., 2005). Primers were from Integrated DNA Tech (Coralville, IA). PCR was performed with a DNA Engine Dyad Peltier Thermal Cycler (BioRad, Hercules, CA) using Hot Start GoTaq (Promega, Madison, WI) using $0.1 \mu \mathrm{M}$ concentration for primers and $2 \mu \mathrm{l}$ of template. The amplification program started with initial denaturation for $3 \mathrm{~min}$ at $95^{\circ} \mathrm{C}$, followed by 35 cycles of denaturation for $30 \mathrm{~s}$ at $94^{\circ} \mathrm{C}$, primer annealing for $30 \mathrm{~s}$ at $57^{\circ} \mathrm{C}$ and extension for $90 \mathrm{~s}$ at $72^{\circ} \mathrm{C}$. The program ended with a final extension for $7 \mathrm{~min}$ at $72^{\circ} \mathrm{C}$. PCR was performed thrice on each sample and amplicons were pooled. Negative controls were run for every PCR.

After verifying fragment sizes with electrophoresis, PCR products were digested using HaeIII restriction enzyme (New England Biolabs, Ipswich, MA) overnight at $37^{\circ} \mathrm{C}$; then, samples were purified using the Qiaquick Nucleotide Removal Kit (Qiagen, Valencia,CA). T-RFLP profiles were generated at the Ohio State Plant Microbe Genomics Facility on an Applied Biosytems 3730 DNA Analyzer (Foster, CA). Peaks with heights comprising $>0.5 \%$ of cumulative peak height between 50 and 600 bp were retained for analysis.
Statistical analysis

Results of the two experiments were analyzed separately. Statistical tests were considered significant at the level $\alpha=0.05$. $T$ tests were performed to examine differences in relative sugar and phenol concentrations between leachates used in the two experiments.

Two-way ANOVA was used to examine the influence of leaf leachate on bacteria numbers (stained by DAPI or FISH), pH, and DOC concentration (i.e., we tested for effects of species 1 treatment, species 2 treatment, and an interaction between species 1 and 2 treatments). A significant interaction effect in this ANOVA supports the hypothesis that mixing of leaf leachate of different species impacts the response variable in question. Final $\mathrm{pH}$ and DOC values for each treatment were also compared to initial values by $t$ tests.

For T-RFLP profiles, statistical significance of differences among treatments within each experiment was determined by redundancy analysis according to a two-way ANOVA design (Legendre \& Anderson, 1999; Blackwood \& Buyer, 2007). Analyses were conducted using one ecological distance metric that includes information contained in peak height (Hellinger distance) and one that includes presenceabsence information (Jaccard distance). Distancebased redundancy analysis was performed using the software Canoco (MicroComputer Power, Ithaca, NY), with the significance assessed by 999 random permutations (Legendre \& Anderson, 1999). The similarity of the glucose-amended community to control was assessed in a separate principal components analysis (PCA) ordination after Hellinger-transformation (Legendre \& Gallagher, 2001).

\section{Results}

Physical and chemical parameters

Physical and chemical parameters on the two dates on which tiles were deployed are presented in Table 1. There were typical seasonal changes in several parameters (such as DOC, $\mathrm{pH}$, and temperature) between the two dates.

General chemical characteristics of the initial leaf leachate are presented in Table 2. There were similar 
Table 1 Environmental variables measured at the site used for biofilm development

\begin{tabular}{lllllllll}
\hline Date & $\mathrm{pH}$ & $\begin{array}{l}\text { Temperature } \\
\left({ }^{\circ} \mathrm{C}\right)\end{array}$ & $\begin{array}{l}\text { Conductivity } \\
(\text { us/cm })\end{array}$ & FV (M/S) & $\begin{array}{l}\text { DOC } \\
(\mathrm{mg} / \mathrm{l})\end{array}$ & $\begin{array}{l}\text { Nitrate/Nitrite } \\
(\mathrm{mg} \text { N/l })\end{array}$ & $\begin{array}{l}\text { SRP } \\
(\mathrm{mg} \text { P/l })\end{array}$ & $\begin{array}{l}\text { Turbidity } \\
(\mathrm{NTU})\end{array}$ \\
\hline 29Nov2007 & $8.4(0.07)$ & $4.3(0.09)$ & $175.0(25.00)$ & $0.39(0.02)$ & $16.7(0.37)$ & $0.89(0)$ & $15.1(0.72)$ & $5.91(0.19)$ \\
23Feb2008 & $6.4(0.11)$ & $2.0(0.13)$ & $269.5(0.97)$ & $0.27(0.01)$ & $8.8(0.11)$ & $0.88(0.02)$ & ND & $5(0)$ \\
\hline
\end{tabular}

$N=3$; Numbers in parentheses are standard errors

$F V$ flow velocity, $N T U$ nephelometric turbidity units, $N D$ not determined, $S R P$ soluble reactive phosphate

Table 2 Chemical parameters of leaf leachate

\begin{tabular}{llll}
\hline & $\begin{array}{l}\text { mg DON/ } \\
\text { mg DOC }\end{array}$ & $\begin{array}{l}\text { Relative sugar } \\
\text { concentration }^{\mathrm{a}}\end{array}$ & $\begin{array}{l}\text { Relative phenolic } \\
\text { concentration }^{\mathrm{b}}\end{array}$ \\
\hline Maple & 0.02 & $0.94(0.10)$ & $0.56(0.00)$ \\
Oak & 0.03 & $1.17(0.11)$ & $0.16(0.13)$ \\
Beech & 0.03 & $0.87(0.11)$ & $0.31(0.31)$ \\
Witch hazel & 0.01 & $0.90(0.11)$ & $0.34(0.02)$ \\
\hline
\end{tabular}

$N=3$ for sugar and phenol analysis. $N=1$ for DON measurement. Numbers in parentheses are standard errors

a Glucose equivalents/mg DOC

b Tannic acid equivalents/mg DOC

relative sugar concentrations (total sugar concentration/DOC concentration) between maple leachate and oak leachate $(P>0.05, t$ test $)$, but relative phenol concentration (total phenol concentration/DOC concentration) of maple leachate was significantly higher than that of oak leachate $(P<0.05, t$ test $)$. In contrast, relative sugar and phenol concentrations were not different between beech and witch hazel leachate $(P>0.05, t$ test $)$.

$\mathrm{pH}$ and DOC concentrations in the experimental units were measured before and after the experiments. The initial $\mathrm{pH}$ of the ASW was 6.4 and DOC concentrations were $15 \mathrm{mg} / \mathrm{l}$ in DOM-treated units. $\mathrm{pH}$ and DOC concentrations at the end of both experiments are shown in Table 3. Final $\mathrm{pH}$ was unaffected by treatment $(P>0.05)$, but increased relatively to the initial $\mathrm{pH}$ of the ASW $(P<0.05$ for all treatments). DOC concentrations declined over time from the initial concentrations added as expected due to heterotrophic activity $(P<0.05$ for all treatments); DOC concentration increased in controls because of the biofilm present on the tiles at the time of inoculation.

In the first experiment, final DOC concentration was significantly higher (relative to other treatments and controls) in units amended with maple leachate $(F=27.44, P<0.05)$, but was not affected by oak leachate $(F=2.90, P>0.05)$, or the interaction between maple and oak leachate $(F=3.90$, $P>0.05)$. In the second experiment, final DOC concentrations were significantly higher in both beech $(F=21.30, P<0.05)$ and witch hazel leachate amendments relative to controls $(F=6.50$, $P<0.05$; Table 3). The interaction between beech and witch hazel leachate was also significant $(F=34.34, P<0.001)$. For the glucose-amended beakers, final $\mathrm{pH}$ was similar to that of the controls $(P>0.05, t$ test $)$, while final DOC concentration was significantly higher than the controls $(P=0.05, t$ test $)$.

\section{Bacterial abundance}

In the first experiment, total bacterial number on the tiles (based on DAPI staining) was not significantly affected by the treatments $(P>0.05$; Fig. 1a). In the second experiment, total bacterial numbers were significantly higher in witch hazel leachate-treated

Table $3 \mathrm{pH}$ and DOC concentrations of water in the beakers measured 11 days after the DOM amendment

\begin{tabular}{|c|c|c|c|c|c|c|c|c|c|}
\hline & \multicolumn{4}{|c|}{ Experiment 1} & \multicolumn{5}{|c|}{ Experiment 2} \\
\hline & Control & Maple & Oak & Maple + Oak & Control & Beech & $\begin{array}{l}\text { Witch } \\
\text { hazel }\end{array}$ & $\begin{array}{l}\text { Beech + witch } \\
\text { hazel }\end{array}$ & Glucose \\
\hline $\mathrm{pH}$ & $6.8(0.03)$ & $6.7(0.06)$ & $6.7(0.01)$ & $6.7(0.01)$ & $6.6(0.05)$ & $6.7(0.05)$ & $6.8(0.04)$ & $6.7(0.03)$ & $6.6(0.03)$ \\
\hline $\mathrm{DOC}(\mathrm{mg} / \mathrm{l})$ & $3.3(0.39)$ & $6.7(0.85)$ & $3.4(0.1)$ & $5.0(0.13)$ & $2.0(0.15)$ & $4.2(0.32)$ & $3.8(0.22)$ & $3.5(0.04)$ & $4.5(0.89)$ \\
\hline
\end{tabular}

$N=3$ for each treatment and control; Numbers in parentheses are standard errors 

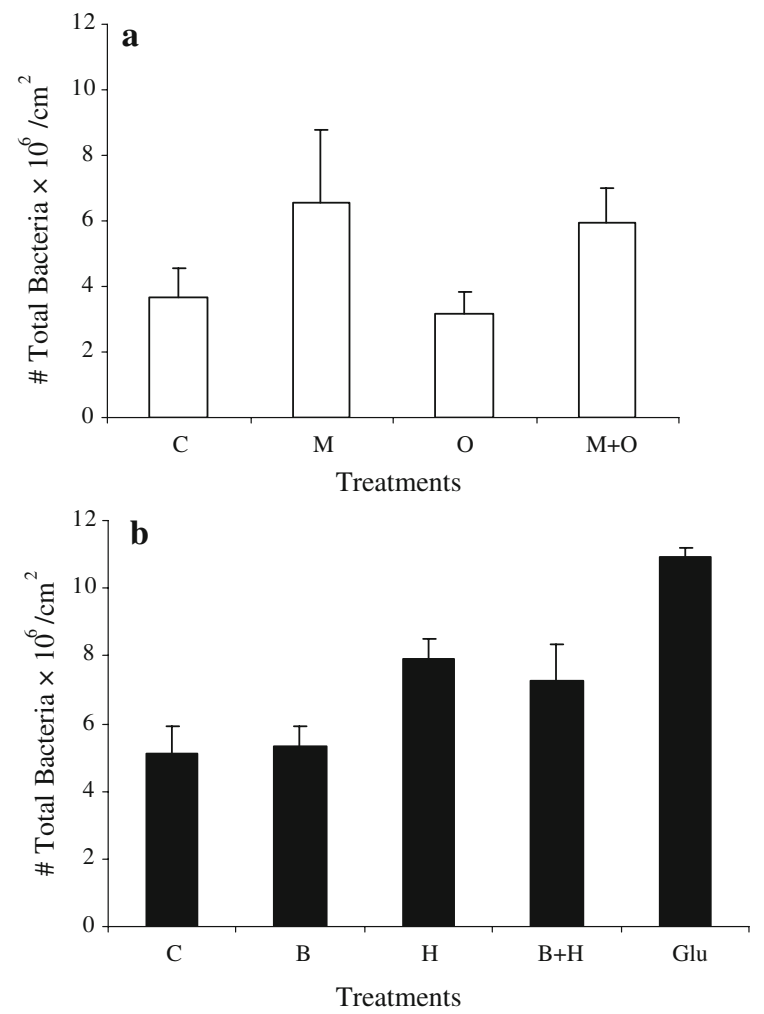

Fig. 1 Mean (+SE) number of total bacteria (determined by DAPI staining on tiles) from the first experiment (a) and the second experiment (b). $C$ control (no amendment); $M$ maple leachate, $O$ oak leachate, $M+O$ maple + oak leachate, $B$ beech leachate, $H$ witch hazel leachate; $B+H$ beech + witch hazel leachate, Glu glucose. $N=3$ for each treatment

beakers $(F=9.18, P<0.05)$, but were unaffected by beech leachate amendment $(F=0.08, P>0.05)$. The interaction between beech and witch hazel treatments was not significant $(F=0.31, P>0.05$; Fig. 1b). During this experiment, there were significantly higher abundances on the glucose-treated tiles than control tiles $(P<0.05, t$ test $)$.

Like total bacterial numbers, there were no significant differences for Beta-Proteobacteria abundance among treatments in the first experiment $(P>0.05$; Fig. 2a). However, in the second experiment, the abundance of Beta-Proteobacteria was significantly higher on tiles incubated in beech leachate compared to tiles not exposed to beech leachate $(F=5.48$, $P<0.05)$ but was not significantly affected by witch hazel leachate $(F=3.17, P>0.05)$ or the interaction of beech and witch hazel $(F=0.01, P>0.05$; Fig. 2b). The number of Beta-Proteobacteria after
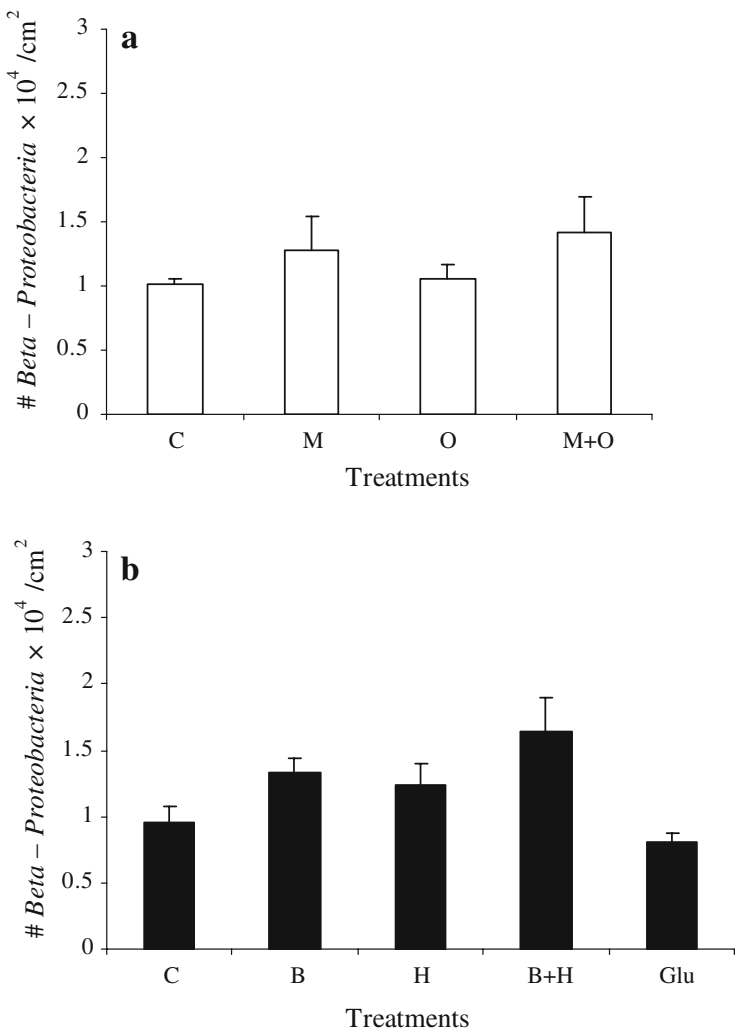

Fig. 2 Mean (+SE) abundance of Beta-Proteobacteria (determined by FISH) on tiles from the first experiment (a) and the second experiment (b). $C$ control (no amendment), $M$ maple leachate, $O$ oak leachate, $M+O$ maple + oak leachate, $B$ beech leachate, $H$ witch hazel leachate, $B+H$ beech + witch hazel leachate, $G l u$ glucose. $N=3$ for each treatment

glucose treatment was not significantly different than the control $(P>0.05, t$ test $)$.

The number of Gamma-Proteobacteria in the biofilms differed among different leaf leachate treatments. In the first experiment, abundance of GammaProteobacteria was significantly higher in the maple leachate amendment than in beakers without maple leachate $(F=6.81, P<0.05)$. In contrast, there was no significant effect of oak leachate treatment $(F=$ $0.68, P>0.05)$; also there was no significant interaction between maple and oak leachate $(F=1.16$, $P>0.05$; Fig. 3a).

In the second experiment, the abundance of Gamma-Proteobacteria was significantly higher in beakers amended with witch hazel leachate compared to those without witch hazel $(F=12.54, P<0.01)$. No significant effect was found with beech leachate amendment $(F=3.07, P>0.05)$; also there was not 

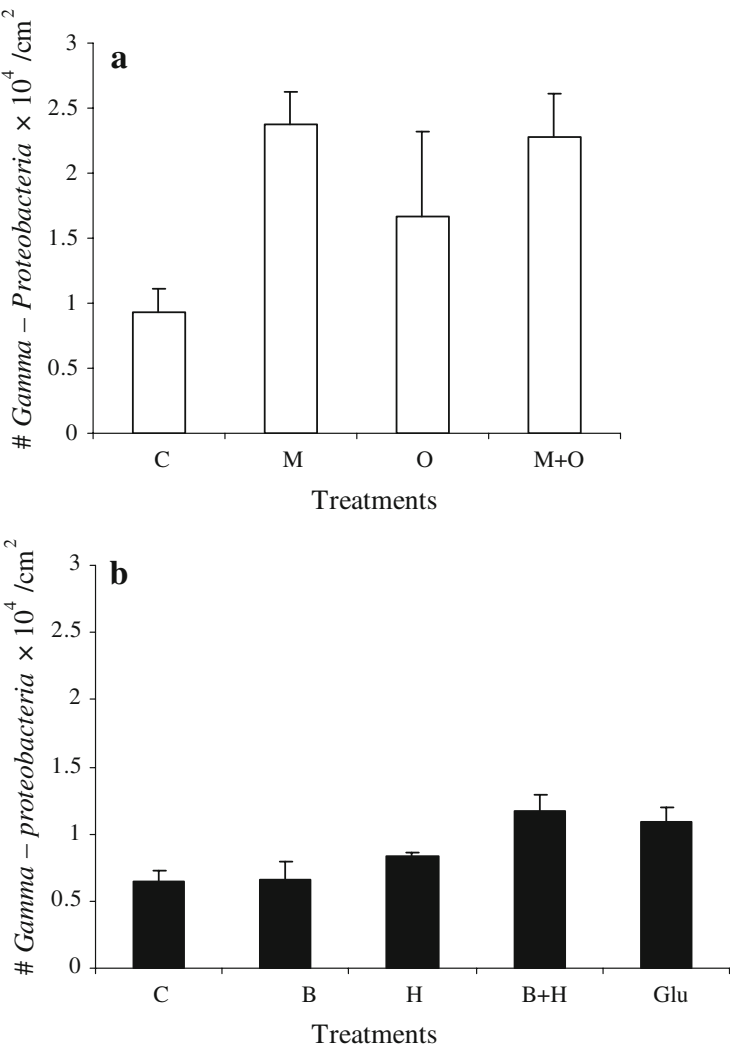

Fig. 3 Mean (+SE) abundance of Gamma-proteobacteria (determined by FISH) on tiles from the first experiment (a) and the second experiment (b). $C$ control (no amendment), $M$ maple leachate, $O$ oak leachate, $M+O$ maple + oak leachate, $B$ beech leachate, $H$ witch hazel leachate, $B+H$ beech + witch hazel leachate, Glu glucose. $N=3$ for each treatment

a significant interaction between beech and witch hazel leachate treatments $(F=2.54, \quad P>0.05$; Fig. 3b). The numbers of Gamma-Proteobacteria after glucose amendment were significantly higher than the controls $(P<0.05, t$ test $)$.

No significant differences were observed among different leaf leachate treatments, in either experiment, for A. calcoaceticus $(P>0.05$; Fig. $4 \mathrm{a}$ and $\mathrm{b})$. A. calcoaceticus numbers were significantly higher on tiles treated with glucose than the controls $(P<0.01, t$ test; Fig. 4b).

When B. cepacia was examined, numbers were significantly lower in response to oak leachate amendment $(F=11.72, P<0.01)$ but not influenced by maple leachate amendment $(F=2.72, P>0.05)$; the interaction between maple and oak leachate treatments was not significant $(F=2.36, P>0.05$; Fig. 5a). In the second experiment, there were no
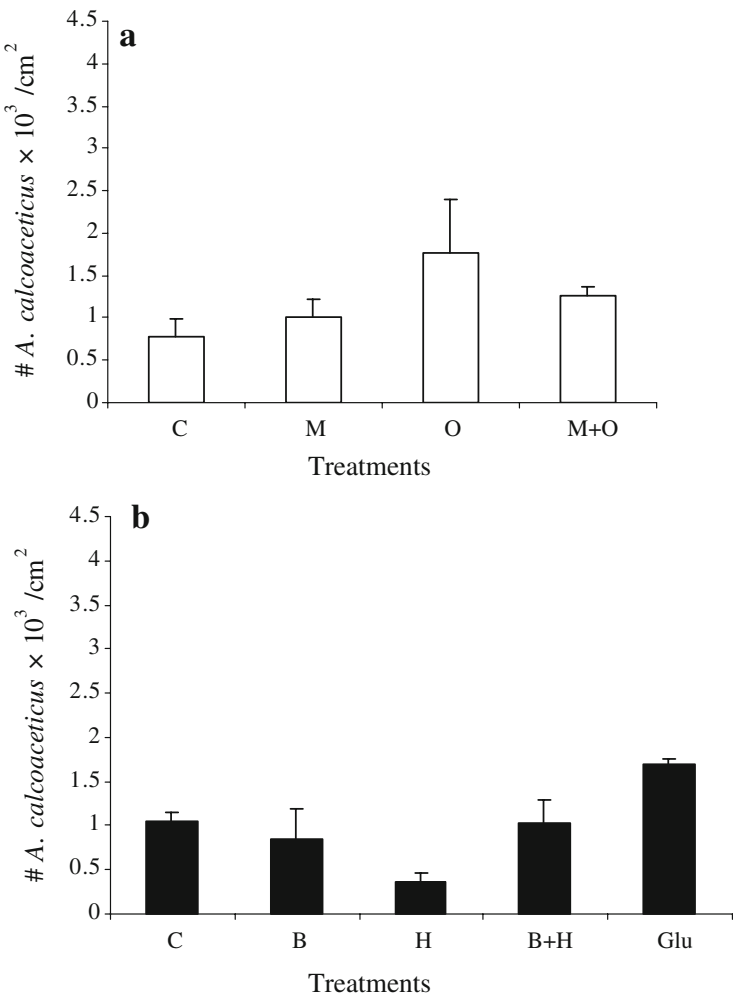

Fig. 4 Mean (+SE) abundance of A. calcoaceticus (determined by FISH) on tiles from the first experiment (a) and the second experiment (b). $C$ control (no amendment), $M$ maple leachate, $O$ oak leachate, $M+O$ maple + oak leachate, $B$ beech leachate, $H$ witch hazel leachate, $B+H$ beech + witch hazel leachate, $G l u$ glucose. $N=3$ for each treatment

significant effects of beech leachate $(F=0.13$, $P>0.05)$, witch hazel, $(F=0.00, P>0.05)$, or interaction between beech and witch hazel leachate $(F=0.43, P>0.05$; Fig. $5 b)$. Likewise, differences in B. cepacia numbers on tiles treated with glucose were not statistically significant different than the controls $(P>0.05, t$ test $)$.

In general, the total abundance of bacteria, as well as abundance of specific groups, before the beginning of the experiment was not substantially different from the average abundances across treatments after the experiment, implying that experimental incubation in the laboratory did not have a large effect independent of the treatments imposed (data not shown). One exception was A. calcoaceticus, which was approximately four times more abundant on tiles before the experiment $\left(483 \mathrm{cells} / \mathrm{cm}^{2}\right.$ ) than afterward (average across treatments was $121 \mathrm{cells} / \mathrm{cm}^{2}$ ). 

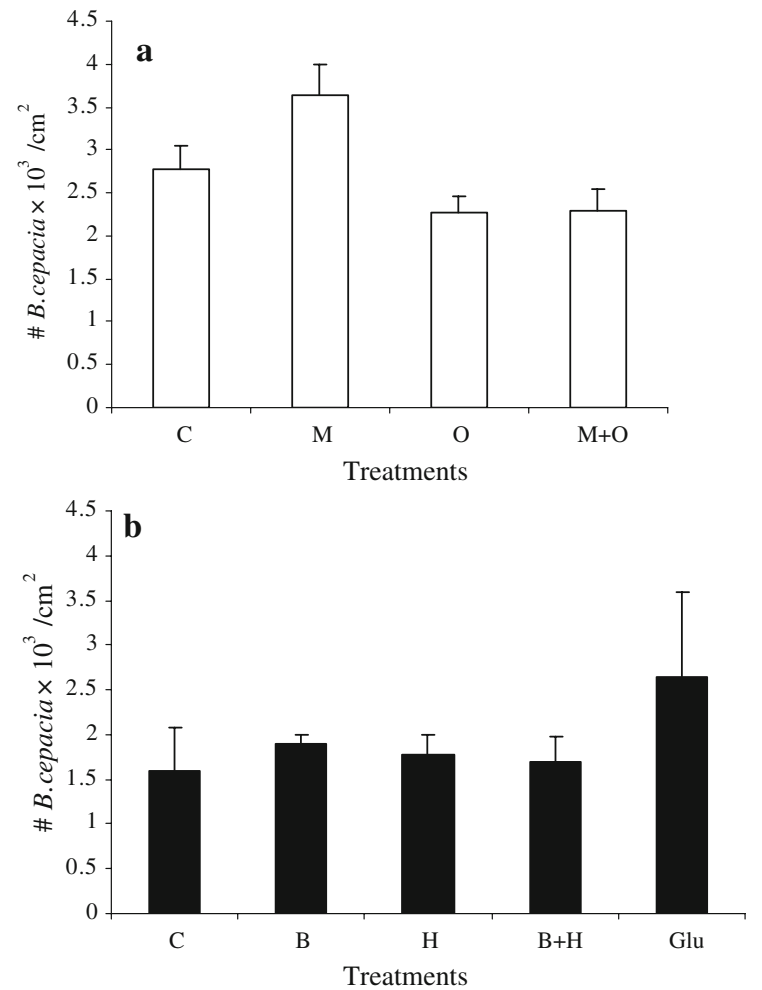

Fig. 5 Mean (+SE) abundance of B. cepacia (determined by FISH) on tiles from the first experiment (a) and the second experiment (b). $C$ control (no amendment), $M$ maple leachate, $O$ oak leachate, $M+O$ maple + oak leachate, $B$ beech leachate, $H$ witch hazel leachate, $B+H$ beech + witch hazel leachate, Glu glucose. $N=3$ for each treatment

\section{Bacterial community composition}

T-RFLP was used to examine differences in bacterial community composition among treatments (see Supplementary Material for additional details). In the first experiment, there was no significant effect of maple, oak, or maple + oak interaction $(P>0.05$, Fig. 6a). However, in the second experiment (Fig. 6b), T-RFLP profiles were significantly affected by DOM amendment; the beech, witch hazel, beech + witch hazel interaction together accounted for $35 \%$ of total variability in Jaccard distance between profiles $(P<0.05)$. When beech, witch hazel, and interaction effects were tested individually, only the witch hazel treatment was significant, accounting for $19 \%$ of variability in Jaccard distance $(P<0.05)$, and $27 \%$ of variability in Hellinger distance between profiles $(P=0.067)$. This is apparent in the PCA plot in Fig. 6b, where control and beech-amended communities are grouped in the upper
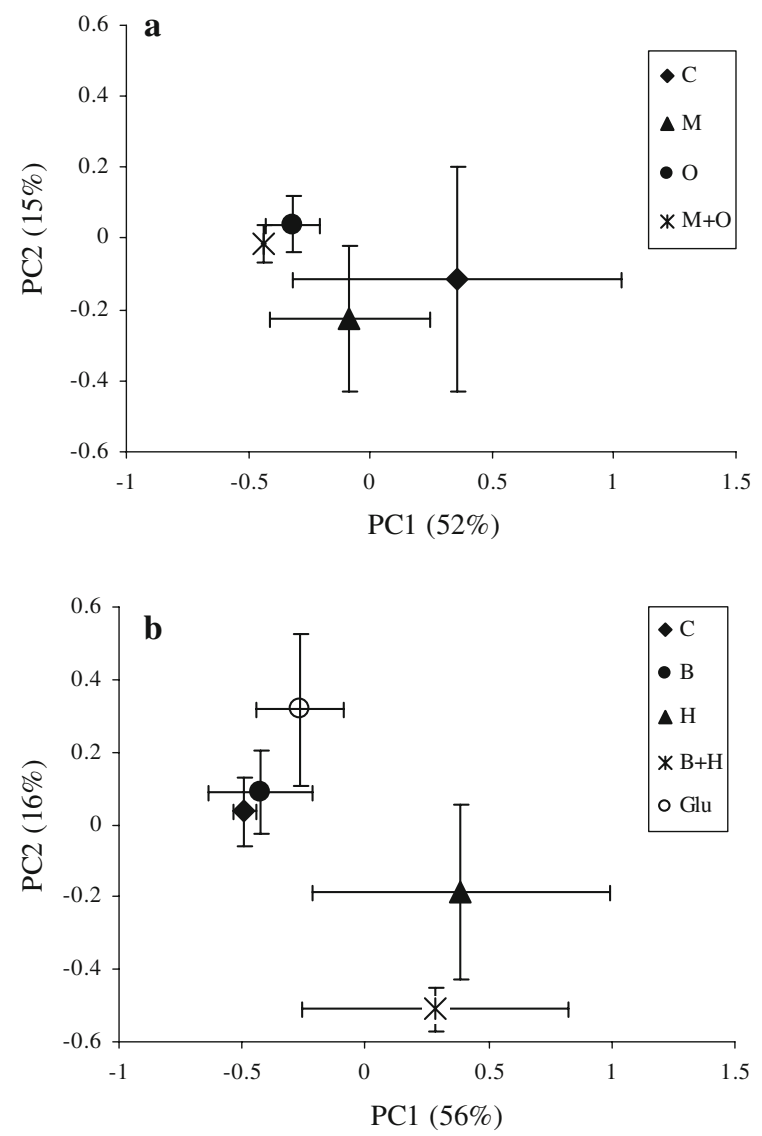

Fig. 6 Principal components plot from bacterial T-RFLP profiles in different DOM treatments from the first experiment (a) and the second experiment (b). $C$ control (no amendment), $M$ maple leachate, $O$ oak leachate, $M+O$ maple + oak leachate, $B$ beech leachate, $H$ witch hazel leachate, $B+H$ beech + witch hazel leachate, $G l u$ glucose. $N=3$ for each treatment

left, separate from witch hazel and beech + witch hazel-amended communities which are grouped in the lower right. Figure $6 \mathrm{~b}$ also shows that glucose amendment had no affect on bacterial community composition, since this treatment is grouped with the control and beech-amended communities. There was an effect of removing tiles from the stream and incubating in the lab, in that, initial community profiles were separated from post-experiment communities by Hellinger PCA ordination of both experiments (data not shown).

\section{Discussion}

DOM is the dominant component of the detrital pool in freshwater systems (e.g., Meyer, 1994; Farjalla 
et al., 2006) and is readily used by bacteria. There is ample evidence from a variety of studies that bacteria are limited by the availability of labile organic molecules; however, responses to DOM amendment are not always consistent with expectations (e.g., McArthur \& Marzolf, 1986; McArthur et al., 1994; Koetsier et al., 1997; Eiler et al., 2003). Our findings suggest that the unpredictable responses may be at least partially attributable to variability in bacterial community composition as responses varied among bacterial taxa.

Although perhaps not all bacteria use leaf leachate effectively as a carbon source, the community was able to effectively degrade the DOM added based on the observed declines in DOC concentration. At the same time, however, the effects of differences in phenolics were reflected in utilization of DOM because loss of DOC from oak (which had lower phenolic concentrations)-treated units was greater than that of maple. Beyond this, we also found that mixing of leachate from different species could increase degradation. Specifically, mixtures of beech and witch hazel were utilized more than leachate from either leaf species alone demonstrating that mixing of leachate may increase its utilization. Glucose amendment generally elicited a positive response consistent with earlier investigations (Gurung \& Urabe, 1999; Skoog et al., 2002; Olapade \& Leff, 2005, 2006). Collectively, this study reinforces the bacterial preference of carbohydrates because of their extreme lability and common occurrence in streams (Chappelle, 1993).

Our results support the prediction that responses to leaf leachate would differ among the various bacterial groups examined. All groups of bacteria examined, except one, responded to one or more leaf leachate treatments. Specifically, the abundance of Gammaproteobacteria was elevated when exposed to maple and witch hazel leachate, whereas Beta-proteobacteria were stimulated by beech leachate. At the species level, B. cepacia abundance was suppressed by oak leachate, whereas A. calcoaceticus did not respond to any leachate amendments. These results are consistent with those of Olapade \& Leff (2006) and McNamara \& Leff (2004a). Olapade \& Leff (2006) found that the number of Gamma-proteobacteria was not affected by leaf leachate exposure but Beta-proteobacteria, A. calcoaceticus and B. cepacia numbers were highest on tiles, in some seasons, after leachate amendments.
McNamara \& Leff (2004a) reported no differences in the number of $A$. calcoaceticus after leachate treatment, while $B$. cepacia responded positively.

Community structure, based on T-RFLP fingerprinting, responded to only one of the leachate types examined, witch hazel. Witch hazel plants contain secondary compounds, including those widely known for their medicinal qualities, such as polyphenols, that have clear antioxidant properties (i.e., as free radical scavengers) (Tourino et al., 2008). Therefore, differences between the leachate chemistry of witch hazel and other leaf types likely exist but were not detected by our broad chemical measurements. We hypothesize that the general bacterial community responses observed reflect the effects of high concentrations of particular classes of compounds, such as proanthocyanidins, which have significant impacts on cell function (Cos et al., 2004).

The absence of significant effects of leaf leachate on community structure, other than for witch hazel, is surprising, given that each of the other leaf leachate types significantly affected abundance of at least one taxon detected through FISH, and that the phylogenetic groups differed in their responses to leaf leachates. One potential explanation is that the groups chosen for examination by FISH were purposefully selected because they were likely to respond to different treatments based on prior studies (McNamara \& Leff, 2004a, b; Olapade \& Leff, 2005, 2006), whereas the T-RFLP analysis included many other groups that did not differentially respond to leaf leachates (other than witch hazel), as well as DNA from inactive, dormant or senescent cells. Cells detected by group-specific FISH represented less than $1 \%$ of those detected by DAPI staining, reinforcing this possibility.

We found no evidence supporting our hypothesis that bacterial responses would differ between monospecific and mixed-species leachate, in spite of the observed differences in DOC use in mixed versus monospecific leachate. This was unexpected given that the growth of microorganisms in a mixture of substrates is greater than when only one substrate is available (Egli, 1995). Although the specific chemical composition of the leaf leachate used is unknown and not fully definable, it seems likely that mixing leachates from different species enhances substrate heterogeneity. Perhaps the response of a community to increasing diversity of compounds saturates at a 
level of compound diversity much lower than is present in leaf leachate or measures of overall bacterial production would have revealed an affect of mixing leachates. DOM in this study was derived strictly from leaves, but there is also the potential for metabolites produced by microbial communities on different leaf types to have an effect on biofilm communities. In addition, it is possible that community responses are regulated by colonization of bacteria from adjacent leaf types, resulting in a succession which was not captured in this laboratory experiment.

Potentially there are many abiotic and biotic factors that limit biofilm bacteria in freshwater systems. DOM, in particular, has received much attention. Although findings demonstrating DOM limitation are mixed (Sun et al., 1997; McNamara \& Leff, 2004a; Docherty et al., 2006; Olapade \& Leff, 2006), perhaps because the nature and composition of the DOM pool is not fully accounted for, there is evidence that increasing availability of labile DOM can alter bacterial community structure (Cottrell \& Kirchman, 2000) and function (Wehr et al., 1999; Strauss \& Lamberti, 2002). Our findings demonstrate that leaf leachate can be readily degraded but that the effects of differences in leaf leachate were very group-specific. Mixing of leaf species had no impact on community structure but, in one of the two experiments, enhanced overall DOC utilization. However, the occurrence of particular compounds, such as those in witch hazel, may alter general community structure suggesting that the presence and abundance of specific plant taxa can play an important role in structuring bacterial communities.

Acknowledgments We are grateful to C. Clevinger, R. Vukanti, and L. Feinstein for their assistance and financial support from China scholarship fund (2006A62008).

\section{References}

Amann, R. I., L. Krumholz \& D. A. Stahl, 1990. Fluorescentoligonucleotide probing of whole cells for determinative phylogenetic and environmental studies in microbiology. Journal of Bacteriology 172: 762-770.

Amann, R. I., W. Ludwig \& K. H. Schleifer, 1995. Phylogenetic identification and in situ detection of individual microbial cells without cultivation. Microbiology and Molecular Biology Reviews 59: 143-169.
APHA (American Public Heath Association), 1998. Standard Methods for the Examination of Water and Wastewater, 20th ed. American Public Health Association, Washington, DC.

Araya, R., K. Tanik, T. Takagi, N. Tamaguchi \& M. Nasu, 2003. Bacterial activity and community composition in stream water and biofilms from an urban river determined by fluorescent in situ hybridization and DGGE analysis. FEMS Microbiology Ecology 43: 111-119.

Battin, T. J., L. A. Kapian, J. D. Newbold \& C. M. E. Hansen, 2003. Contributions of microbial biofilms to ecosystem processed in stream mesocosms. Nature 426: 439-442.

Blackwood, C. B. \& J. S. Buyer, 2007. Evaluating the physical capture method of terminal restriction fragment length polymorphism for comparison of soil microbial communities. Soil Biology and Biochemistry 39: 590-599.

Blackwood, C. B., A. Oaks \& J. S. Buyer, 2005. Phylum- and class-specific PCR primers for general microbial community analysis. Applied and Environmental Microbiology 71: 6193-6198.

Blackwood, C. B., C. J. Dell, A. J. M. Smucker \& E. A. Paul, 2006. Eubacterial communities in soil macroaggregate environments and cropping systems. Soil Biology and Biochemistry 38: 720-728.

Bouvier, T. \& P. A. Giorgio, 2003. Factors influencing the detection of bacterial cells using fluorescence in situ hybridization (FISH): a quantitative review of published reports. FEMS Microbiology Ecology 44: 3-15.

Chappelle, F. H., 1993. Ground-Water Microbiology and Geochemistry. Wiley, New York.

Cleveland, C. C., J. C. Neff, A. R. Townsend \& E. Hood, 2004. Composition, dynamics, and fate of leached dissolved organic matter in terrestrial ecosystems: results from a decomposition experiment. Ecosystems 7: 275-285.

Cos, P., T. D. Bruyne, N. Hermans, S. Apers, D. V. Berghe \& A. J. Vlietinck, 2004. Proanthocyanidins in health care: current and new trends. Current medicinal chemistry 11: 1345-1359.

Cottrell, N. T. \& D. L. Kirchman, 2000. Natural assemblages of marine proteobacteria and members of the CytophagaFlavobacter cluster consuming low- and high-molecularweight dissolved organic matter. Applied and Environmental Microbiology 66: 1692-1697.

Danovaro, R., G. M. Luna, A. D. Anno \& B. Pietrangeli, 2006. Comparison of two fingerprinting techniques, terminal restriction fragment length polymorphism and automated ribosomal intergenic spacer analysis, for determination of bacterial diversity in aquatic environments. Applied and Environmental Microbiology 72: 5982-5989.

DeLong, E. F., G. S. Wickham \& N. R. Pace, 1989. Phylogenetic stains: ribosomal RNA-based probes for the identification of single cells. Science 243: 1360-1363.

Docherty, K. M., K. C. Young, P. A. Maurice \& S. D. Bridgham, 2006. Dissolved organic matter concentration and quality influences upon structure and function of freshwater microbial communities. Microbial Ecology 52: 378-388.

Dubois, M., D. A. Gilles, J. K. Hamilton, P. A. Rebers \& F. Smith, 1956. Colorimetric method for the determination of sugars and related substances. Analytical Chemistry 28: 350-356. 
Egli, T., 1995. The ecological and physiological significance of the growth of heterotrophic microorganisms with mixtures of substrates. In Jones, J. G. (ed.), Advances in Microbial Ecology. Plenum press, New York: 305-386.

Eiler, A., S. Langenheder, S. Bertilsson \& L. Tranvik, 2003. Heterotrophic bacterial growth efficiency and community structure at different natural organic concentrations. Applied and Environmental Microbiology 69: 3701-3709.

Farjalla, V. F., D. A. Azevedo, F. A. Esteves, R. L. Bozelli, F. Roland \& A. Enrich-Prast, 2006. Influence of hydrological pulse on bacterial growth and DOC uptake in a ClearWater Amazonian Lake. Microbial Ecology 52: 334-344.

Fierer, N., J. P. Schimel, R. G. Cats \& J. Zou, 2001. Influence of balsam popular tannin fractions on carbon and nitrogen dynamics in Alaskan taiga floodplain soils. Soil Biology and Biochemistry 33: 1827-1839.

Fisher, S. G. \& G. E. Likens, 1973. Energy flow in Bear Brook. New Hampshire: an integrative approach to stream ecosystem metabolism. Ecological monographs 43: 421-439.

Giller, P. \& B. Malmqvist, 1998. The Biology of Rivers and Streams. Oxford University Press, Oxford.

Gurung, T. B. \& J. Urabe, 1999. Temporal and vertical difference in factors limiting growth rate of heterotrophic bacteria in Lake Biwa. Microbial Ecology 38: 136-145.

Hall, J. R., 1995. Use of a stable carbon isotope addition to trace bacterial carbon through a stream food web. Journal of the North American Benthological Society 14: 269-277.

Juni, E., 1978. Genetics and physiology of Acinetobacter. Annual Reviews in Microbiology 32: 349-371.

Kent, A. D., D. J. Smith, B. J. Benson \& E. W. Triplett, 2003. Web-based phylogenetic assignment tool for analysis of terminal restriction fragment length polymorphism profiles of microbial communities. Applied and Environmental Microbiology 69: 6768-6776.

Koetsier, P., J. V. McArthur \& L. G. Leff, 1997. Spatial and temporal response of stream bacteria to sources of dissolved organic carbon in a blackwater stream system. Freshwater Biology 37: 79-89.

Leff, L. G., 2000. Longitudinal changes in microbial assemblages of the Ogeechee River. Freshwater Biology 43: 605-615.

Legendre, P. \& M. J. Anderson, 1999. Distance-based redundancy multifacturial analysis: testing multispecies responses in ecological experiments. Ecological Monographs 69: $1-24$.

Legendre, P. \& E. D. Gallagher, 2001. Ecologically meaningful transformation for ordination of species data. Oecologia 129: 271-280.

Lessie, T. G. \& T. Gaffney, 1986. Catabolic potential of Pseudomonas cepacia. In Sokatch, J. R. (ed.), The Bacteria: A Treatise on Structure and Function. Academic Press, New York: 439-481.

Liu, J. \& L. G. Leff, 2002. Temporal changes in the bacterioplankton of a Northeast Ohio (USA) river. Hydrobiologia 489: 151-159.

Liu, W. T., T. L. Marsh, H. Cheng \& L. J. Forney, 1997. Characterization of microbial diversity by determining terminal restriction fragment length polymorphisms of genes encoding 16S rRNA. Applied and Environmental Microbiology 63: 4516-4522.
Manz, W., K. Wedt-Potthoff, T. R. Neu, U. Szewzyk \& J. R. Lawrence, 1999. Phylogenetic composition, spatial structure, and dynamics of lotic bacterial biofilms investigated by flucorescent in situ hybridization and confocal laser scanning microscopy. Microbial Ecology 37: 225-237.

Marsh, T. L., 1999. Terminal-restriction fragment length polymorphism (T-RFLP): an emerging method for characterizing diversity among homologous populations of amplicons. Current Opinion in Microbiology 2: 323-327.

McArthur, J. V. \& G. R. Marzolf, 1986. Interactions of the bacterial assemblages of a prairie stream with dissolved organic carbon from riparian vegetation. Hydrobiologia 134: 193-199.

McArthur, J. V., J. M. Aho, R. B. Rader \& G. L. Mills, 1994. Interspecific leaf interactions during decomposition in aquatic and floodplain ecosystems. Journal of the North American Benthological Society 13: 57-67.

McNamara, C. J. \& L. G. Leff, 2004a. Response of biofilm bacteria to dissolved organic matter from decomposing maple leaves. Microbial Ecology 48: 324-330.

McNamara, C. J. \& L. G. Leff, 2004b. Bacterial community composition in biofilms on leaves in a northeastern Ohio stream. Journal of the North American Benthological Society 23: 677-685.

Meyer, J. L., 1994. The microbial loop in flowing waters. Microbial Ecology 28: 195-199.

Mulholland, P. J., J. W. Elwood, J. D. Newbold, J. R. Webster, L. A. Ferren \& R. E. Perkins, 1984. Phosphorus uptake by decomposing leaf detritus: effect of microbial biomass and activity. Verhandlung Internationale Vereinigung Limnologie 22: 1899-1905.

Münster, U., 1993. Concentrations and fluxes of organic carbon substrates in the aquatic environment. Antonie van Leeuwenhoek 63: 243-274.

Olapade, O. A. \& L. G. Leff, 2004. Seasonal dynamics of bacterial assemblages in epilithic biofilms in a northeastern Ohio stream. Journal of the North American Benthological Society 23: 687-700.

Olapade, O. A. \& L. G. Leff, 2005. Seasonal response of stream biofilm communities to dissolved organic matter and nutrient enrichments. Applied and Environmental Microbiology 71: 2278-2287.

Olapade, O. A. \& L. G. Leff, 2006. Influence of dissolved organic matter and inorganic nutrients on biofilm bacterial community on artificial substrates in a north-eastern Ohio stream (USA). Canadian Journal of Microbiology 52: 540-549.

Pernthaler, J., O. F. Glöckner, A. A. Unterholzner, R. Psenner \& R. Amann, 1998. Seasonal community and population dynamics of pelagic bacteria and archaea in a high mountain lake. Applied and Environmental Microbiology 64: 4299-4306.

Porter, K. S. \& Y. S. Feig, 1980. The use of DAPI for identifying and counting aquatic microflora. Limnology and Oceanography 25: 943-948.

Rubin, M. A. \& L. G. Leff, 2007. Nutrients and other abiotic factors affecting bacterial communities in an Ohio River (USA). Microbial Ecology 54: 374-383.

Santmire, J. A. \& L. G. Leff, 2007. The influence of stream sediment particular size on bacterial abundance and community composition. Aquatic Ecology 41: 153-160. 
Sasaki, A., S. Shikenya \& K. Takeda, 2007. Dissolved organic matter originating from the riparian shrub Salix gracilistyla. Journal of Forest Research 12: 68-74.

Schlief, J. \& M. Mutz, 2007. Response of aquatic leaf associated microbial communities to elevated leachate DOC: a microcosm study. International Review of Hydrobiology 92: $146-155$.

Singleton, V. L. \& J. A. Rossi, 1965. Colorimetry of total phenolics with phosphomolybdic-phosphotungstic acid reagents. American Journal of Enology and Viticulture 16: $144-158$.

Skoog, A., K. Whitehead, F. Sperling \& K. Junge, 2002. Microbial glucose uptake and growth along a horizontal nutrient gradient in the North Pacific. Limnology and Oceanography 47: 1676-1683.

Strauss, E. A. \& G. A. Lamberti, 2002. Effect of dissolved organic carbon quality on microbial decomposition and nitrification rates in stream sediments. Freshwater Biology 47: 65-74.

Sun, L., E. M. Perdue, J. L. Meyer \& J. Weis, 1997. Use of elemental composition to predict bioavailability of dissolved organic matter in a Georgia river. Limnology and Oceanography 42: 714-721.

Tourino, S., D. Lizarraga, S. Lorenzo, V. Ugartondo, M. Mitjans, M. P. Vinardell, L. Juliá, M. Cascante \& J. L. Torres,
2008. Highly galloylated tannin fractions from witch hazel (Hamamelis virginiana) bark: electron transfer capacity, in vitro antioxidant activity, and effects on skin-related cells. Chemical Research in Toxicology 21: 696-704.

Wallace, T. A., G. G. Ganf \& J. D. Brookes, 2008. A comparison of phosphorus and DOC leachates from different types of leaf litter in an urban environment. Freshwater Biology 53: 1902-1913.

Webster, J. R. \& E. F. Benfield, 1986. Vascular plant breakdown in freshwater ecosystems. Annual Review of Ecology and Systematics 17: 567-594.

Webster, J. R., J. B. Wallace \& E. F. Benfield, 1995. Organic processes in streams of the eastern united states. In Cushing, C. E., K. W. Cummins \& G. W. Minshall (eds), River and Stream Ecosystems. Elsevier Science BV, Amsterdam: 117-187.

Wehr, J. D., J. Petersen \& S. Findlay, 1999. Influence of three contrasting detrital carbon sources on planktonic bacterial metabolism in a mesotrophic lake. Microbial Ecology 37: 23-35.

Wetzel, R. G., 1992. Gradient dominated ecosystems: sources and regulatory functions of dissolved organic matter in freshwater ecosystems. Hydrobiologia 229: 181-198. 